\title{
Effects of crop rotation and residue management on bread wheat
}

\author{
Ahmad Zare Feizabady \\ Department of Crop Science, Khorasan Razavi Agricultural and Natural Resources Research Center, Toroq Station, \\ P. O. Box 91735-488 Mashhad, Iran. E-mail: azarea.2002@yahoo.com.
}

Accepted 16 May, 2012

\begin{abstract}
The objective of this study was to determine the influence of crop rotation and crop residue management on wheat yield and yield components with four crop rotations [wheat-wheat-wheatrapeseed-wheat (WWWRW), wheat-sugar beet-wheat-potato-wheat (WSWPW), wheat-maize-wheatpotato-wheat (WMWPW) and wheat monoculture for the whole period (WWWWW)] and three levels of retaining crop residues to soil $(0,50$ and $100 \%$ produced crop residues to soil) were allocated to main and sub plots, respectively. Results showed that the effect of different crop rotations on the plant height, spike number per square metre, seed number per spike; economic yield and biological yield of wheat were significant. There were significant differences between different levels of crop residues to soil for wheat spike length, spike and seed number. Interaction between different crop rotation and returning crop residues to soil had significant effect on plant height, spike length, seed number, economic and biological yield in wheat. Wheat seed yield were increased 37, 21 and $33 \%$ in WWWRW, WSWPW, WMWPW compared with wheat monoculture, respectively. As this application of crop residues affected wheat yield and yield components, the highest yield was observed in $100 \%$ returning all crop residues to soil. Although the application of adding crop residues to soil is a feasible alternative for farmers to enhance yield, the quantity and quality residue is the main factor for incorporation. Sowing wheat in rotation with rapeseed improved seed yield compared with monoculture.
\end{abstract}

Key words: Crop production, organic matter, straw management, sustainability.

\section{INTRODUCTION}

High and sustainable crop production is linked to improved soil physical, chemical and biological properties, which they are a primary function of soil organic matter (Zentner and Lindwall, 1978; Phillips et al., 1980). Crop residues are a source of organic C for soil microorganisms, and also contribute to plant nutrients. Crop residue retention on the soil surface, substantially reduces run-off and soil erosion, and can decrease soil evaporation and land preparation costs (Lal, 1989). Residue retention can also, over the long term, improve soil structure and water-holding capacity, and residue retention will improve long-term nutrient cycling (Bélair and Parent, 1996). These desirable outcomes of residue retention, some of which take several years to become evident, have been reported extensively for other mainly temperate environments (Blevins and Frye, 1993; Karlen et al., 1994). Effects of crop residue amount were sometimes modified by other management practices such as type of tillage and crop fertilization and, use of cover crops (Maskina et al., 1993).

Agricultural sustainability problems related to soil erosion and fertility decline have arisen throughout this agro-ecological zone (Scherr and Yadav, 1996). From experience elsewhere, a number of technical innovations could offer possibilities for improving the productivity and sustainability of the cropping system. These innovations include crop rotation in order to break soil pathogen cycles, promote higher microbiological activity, facilitate weed control and restore soil fertility (Toderi, 1988; Liu and Lovett, 1990; Bélair and Parent, 1996; Parente, 1996; Chalk, 1998). Diversified crop rotations tend to reduce the development of a few primary weed species by offering different sowing and harvest times, different life cycles and different possibilities for weed control (Liebman and Dyck, 1993). For example, giant foxtail (Setaria faberi Herrm.) seed numbers increased in 
Table 1. Mean monthly rainfall during the study period and maximum and minimum temperatures at Rokh plain, Iran.

\begin{tabular}{lcccccccc}
\hline \multirow{2}{*}{ Month } & \multicolumn{9}{c}{ Rainfall $(\mathbf{m m})$} & $\begin{array}{c}\text { Relative humidity } \\
(\mathbf{m m})\end{array}$ & $\begin{array}{c}\text { Temperature } \\
\left({ }^{\circ} \mathbf{C}\right)\end{array}$ & $\begin{array}{c}\text { Temperature }_{\text {max }} \\
\left({ }^{\circ} \mathbf{C}\right)\end{array}$ \\
\hline & $\mathbf{2 0 0 6}$ & $\mathbf{2 0 0 7}$ & $\mathbf{2 0 0 8}$ & $\mathbf{2 0 0 9}$ & $\mathbf{2 0 1 0}$ & -6.2 & 4.5 \\
January & 20 & 19.4 & 24.4 & 29.2 & 14.3 & 69 & -6 & 4.7 \\
February & 18.6 & 37.9 & 21.4 & 31.8 & 43.8 & 65 & -1.9 & 9.3 \\
March & 46 & 56.4 & 0 & 52.1 & 33.2 & 54 & 3.5 & 16.1 \\
April & 15.8 & 81.1 & 18.4 & 130.7 & 41.7 & 53 & 8.2 & 22 \\
May & 10 & 6.3 & 0.9 & 23.6 & 59 & 39 & 11.5 & 26.8 \\
June & 0 & 1.9 & 3.6 & 0.8 & 0 & 29 & 14.4 & 29.5 \\
July & 0 & 0 & 0 & 0 & 2.2 & 28 & 13.6 & 28.8 \\
August & 0 & 1 & 0 & 0 & 0 & 25 & 10.5 & 26.2 \\
September & 0 & 0 & 0 & 6.6 & 0 & 28 & 6.2 & 21.5 \\
October & 29.2 & 0 & 0.4 & 0 & 0 & 32 & 2.2 & 15.5 \\
November & 46.1 & 0 & 9.4 & 9.7 & 1.3 & 45 & -2.7 & 8.8 \\
December & 29.3 & 27.5 & 9.4 & 33.7 & 0 & 66 & 4.44 & 17.81 \\
Total & 215 & 231.5 & 87.9 & 318.2 & 195.5 & 42.3 & & \\
\hline
\end{tabular}

continuous maize compared to rotations of maize (Zea mays L.)/soybean (Glycine max L.) or maize/soybean/ wheat (Triticum aestivum L.) (Schrieber, 1992). On the other hand, continuous cropping has led to increased weed pressure, weeding frequency, weed-related crop losses and low soil fertility, especially in farming systems where external inputs are not used (Chikoye et al., 2000; Akobundu and Ekeleme, 2002; Kanmegne and Degrande, 2002). Also, crop diversification reduced fallow and decreased inputs are being enhanced to improve economical and environmental sustainability (Peterson et al., 1993). Limon-Ortega et al. (2008) found that crop rotation of wheat-sesbania (Sesbania spp.) compared to wheat-maize and wheat-bare fallow produced the highest grain yield. Totally, in the short-term, benefit of crop rotation is increased crop yield, which would likely increase crop profitability, but in the longterm, rotations with high residue-producing crops increase total soil $\mathrm{C}$ and $\mathrm{N}$ concentrations over time, which may further improve soil productivity.

Intensification of crop production, by reduction of summer fallow frequency, provided more efficient utilization of the scarce water resource in the semiarid central Great Plains (Farahani et al., 1998). The wheat grain quality depends on environmental conditions and cropping practices such as rotation crop. So, LópezBellido et al. (1998) carried out a 3-year field study in a rain fed Mediterranean region on the effects of crop on the grain quality of hard red spring wheat and reported that the crop rotations including a legume, that is, wheatfaba bean and wheat-chickpea had marked effects on wheat quality.

Since, wheat is considered as the main winter cycle crop (Limon-Ortega et al., 2008), the purpose of present study was to examine the effect of different crop rotations and crop residue on yield and yield components for wheat under climatic conditions of Rokh plain in Iran.

\section{MATERIALS AND METHODS}

\section{Location and its climate}

Five field experiments were carried out during five growing seasons of 2006 to 2010 at Agricultural Research Station of Rokh plain, 135 $\mathrm{km}$ southeast of Mashhad, Iran, with latitude of $35^{\circ} 34^{\prime} \mathrm{N}$ and longitude of $59^{\circ} 23^{\prime} \mathrm{E}$, altitude was $1721 \mathrm{~m}$ above sea level and mean annual rainfall: $223 \mathrm{~mm}$. Monthly mean of rainfall, relative humidity, minimum and maximum of temperature are shown in Table 1.

\section{Treatments and agricultural practices}

Four crop rotations including wheat-wheat-wheat-rapeseed-wheat (WWWRW), wheat-sugar beet-wheat-potato-wheat (WSWPW), wheat-maize-wheat-potato-wheat (WMWPW) and wheat monoculture for the whole period (WWWWW)) and three levels of returning crop residues to soil (retain in 0,50 and 100\% produced crop residues to soil) were allocated to main and sub plots, respectively. At the end of growing season and after crop harvesting plant residues returned to the soil by moldboard plow. Wheat line (C-81-4) and rapeseed (CV. Modena) were planted during fall and sugar beet (CV. Rhizophort), potato (CV. Agria) and maize (CV. S.C 370) were sown in the following spring. Soil physical and chemical properties of the site before planting are shown in Table 2.

Row spacing was $60 \mathrm{~cm}$ for all crops. On each row, I had 3 and 2 planting lines for wheat and rapeseed respectively, and for sugar beet, potato and maize, only one planting line was considered. Rate and application time of fertilizers has summarized in Table 3.

Seedbed operations, sowing, seeding rate and crop management (including irrigation, weed, pest and disease control) were carried out according to the common practices applied by local farmers.

\section{Measurements}

Economic yield of all crops measured at the fourth year of 
Table 2. Soil properties before the start of experiment $(0$ to $30 \mathrm{~cm})$.

\begin{tabular}{|c|c|c|c|c|c|c|c|c|c|c|}
\hline \multirow{2}{*}{ N (\%) } & $\mathbf{P}$ & K & B & $\mathrm{Cu}$ & Mn & $\mathrm{Fe}$ & $\mathrm{Zn}$ & \multirow{2}{*}{$\mathrm{OC}(\%)$} & \multirow{2}{*}{$\mathrm{pH}$} & \multirow{2}{*}{$\mathrm{EC}\left(\mathrm{dS} \cdot \mathrm{m}^{-1}\right)$} \\
\hline & & & & $\left(\mathrm{mg}^{\prime} \mathrm{kg}^{-1}\right.$ & & & & & & \\
\hline 0.06 & 10.80 & 174.00 & 2.80 & 1.34 & 6.80 & 3.44 & 0.37 & 0.63 & 8.1 & 2.35 \\
\hline
\end{tabular}

Table 3. Rate of chemical fertilizers application for different crops.

\begin{tabular}{|c|c|c|c|c|c|}
\hline \multirow{2}{*}{ Crops } & \multicolumn{2}{|c|}{$\mathbf{N}\left(\mathbf{k g} \cdot \mathbf{h a}^{-1}\right)$} & \multirow{2}{*}{$\begin{array}{l}\mathrm{P}_{2} \mathrm{O}_{5}\left(\mathrm{~kg}_{\mathrm{h}} \mathrm{ha}^{-1}\right) \\
\text { Before planting }\end{array}$} & \multirow{2}{*}{$\begin{array}{c}\mathrm{K}_{2} \mathrm{O}\left(\mathrm{kg} \cdot \mathrm{ha}^{-1} \text { ) }\right. \\
\text { Before planting }\end{array}$} & \multirow{2}{*}{$\begin{array}{c}\text { Zn }\left(\mathrm{kg} \cdot \mathrm{ha}^{-1}\right) \\
\text { Before planting }\end{array}$} \\
\hline & Before planting & Top-dressing & & & \\
\hline Wheat & 46 & 115 & 83 & 50 & 10 \\
\hline Rapeseed & 46 & 92 & 83 & 50 & 10 \\
\hline Sugar beet & 69 & 92 & 83 & 50 & 10 \\
\hline Potato & 69 & 69 & 76 & 100 & 10 \\
\hline Maize & 65 & 129 & 83 & 50 & 10 \\
\hline
\end{tabular}

Table 4. The effects of different levels of returning crop residue to soil on crop economic yield (kg.ha-1) for wheat, rape seed, sugar beet, potato and maize in different crop rotation.

\begin{tabular}{|c|c|c|c|c|c|}
\hline \multirow{2}{*}{ Crop rotation } & \multirow{2}{*}{ Returning crop residues to soil (\%) } & \multicolumn{4}{|c|}{ Economic yield $\left(\mathrm{kg} \cdot \mathrm{ha}^{-1}\right)$} \\
\hline & & 2007 & 2008 & 2009 & 2010 \\
\hline \multirow{3}{*}{ WWWRW } & 0 & $5542.0 \mathrm{~W}^{*}$ & $3698.0 \mathrm{~W}$ & $3681.0 \mathrm{~W}$ & $7006.0 \mathrm{~W}$ \\
\hline & 50 & $6252.0 \mathrm{~W}$ & $3934.0 \mathrm{~W}$ & $3896.0 \mathrm{R}$ & $8071.0 \mathrm{~W}$ \\
\hline & 100 & $6011.0 \mathrm{~W}$ & $3904.0 \mathrm{~W}$ & $3889.0 \mathrm{R}$ & $8488.0 \mathrm{~W}$ \\
\hline \multirow{3}{*}{ WSWPW } & 0 & $77833.0 \mathrm{~S}$ & $3838.0 \mathrm{~W}$ & $21519.0 \mathrm{P}$ & $7033.0 \mathrm{~W}$ \\
\hline & 50 & $86667.0 \mathrm{~S}$ & $3594.0 \mathrm{~W}$ & 25407.0 P & $6514.0 \mathrm{~W}$ \\
\hline & 100 & $81333.0 \mathrm{~S}$ & $4528.0 \mathrm{~W}$ & $23130.0 \mathrm{P}$ & $7279.0 \mathrm{~W}$ \\
\hline \multirow{3}{*}{ WMWPW } & 0 & $49491.0 \mathrm{M}$ & $4438.0 \mathrm{~W}$ & $19012.0 \mathrm{P}$ & $7524.0 \mathrm{~W}$ \\
\hline & 50 & $57942.0 \mathrm{M}$ & $4090.0 \mathrm{~W}$ & $22668.0 \mathrm{P}$ & $7538.0 \mathrm{~W}$ \\
\hline & 100 & $58461.0 \mathrm{M}$ & $4644.0 \mathrm{~W}$ & $25790.0 \mathrm{P}$ & $7970.0 \mathrm{~W}$ \\
\hline \multirow{3}{*}{ WWWWW } & 0 & $5792.0 \mathrm{~W}$ & $3386.0 \mathrm{~W}$ & $5607.0 \mathrm{~W}$ & $5751.0 \mathrm{~W}$ \\
\hline & 50 & $6972.0 \mathrm{~W}$ & $3505.0 \mathrm{~W}$ & $6163.0 \mathrm{~W}$ & $5873.0 \mathrm{~W}$ \\
\hline & 100 & $6417.0 \mathrm{~W}$ & $3506.0 \mathrm{~W}$ & $5430.0 \mathrm{~W}$ & $5639.0 \mathrm{~W}$ \\
\hline
\end{tabular}

W, R, S, P and M are wheat, rapeseed, sugar beet, maize and potato, respectively.

experiment. Also, plant samples in the final year of study were taken to measure the yield and yield components of wheat including plant height $(\mathrm{cm})$, spike length $(\mathrm{mm})$, spike number per square meter, seed number per spike, seed weight per spike, 1000-seed weight $(\mathrm{g})$, economic and biological yield at the end of experimental period.

\section{Statistical analysis}

Field experiments were designed as split plot based on randomized complete block design with three replications and data were statistically analyzed using Minitab Ver. 13. Means were compared by Duncan's multiple range test ( $p \leq 5 \%)$ using Mstat-C software.

\section{RESULTS}

\section{Seed yield}

The effects of different crop rotation and levels of returning crop residue to soil on crop economic yield are shown in Table 4.

At the last year of experiment, the maximum wheat economical yield was obtained in WWWRW and $100 \%$ returning crop residue to soil $\left(8488.0 \mathrm{~kg} . \mathrm{ha}^{-1}\right)$. The highest economic yield of rape seed, sugar beet, potato and maize were $3896.0,86667.0,25790.0$ and 58461.0 


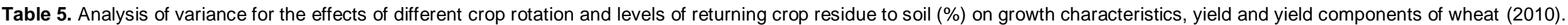

\begin{tabular}{|c|c|c|c|c|c|c|c|c|c|}
\hline Source of variation & df & Plant height & Spike length & Spike number & Seed number & Spike weight & 1000-seed weight & Economic yield & Biological yield \\
\hline Replication & 2 & $19.968^{\text {ns }}$ & $143.028^{\text {ns }}$ & 2488.694 & $1.898^{\mathrm{ns}}$ & $0.004^{\mathrm{ns}}$ & $8.102^{\mathrm{ns}}$ & $36565.028^{\mathrm{ns}}$ & $1117693.750^{\text {ns }}$ \\
\hline Crop rotation $(A)$ & 3 & $241.816^{*}$ & $65.000^{\mathrm{ns}}$ & $43546.250^{*}$ & $32.736^{*}$ & $0.053^{\mathrm{ns}}$ & $4.660^{\mathrm{ns}}$ & $8195845.361^{* *}$ & $7459737.037^{\star}$ \\
\hline Error & 6 & 39.713 & 61.694 & 854.139 & 7.139 & 0.039 & 8.248 & 683284.361 & 342108.565 \\
\hline Crop residue (B) & 2 & $9.508^{\mathrm{ns}}$ & $140.778^{*}$ & $5742.528^{*}$ & $44.871^{*}$ & $0.075^{\mathrm{ns}}$ & $3.539^{\mathrm{ns}}$ & $827039.361^{\mathrm{ns}}$ & $544543.750^{\mathrm{ns}}$ \\
\hline$A \times B$ & 6 & $11.973^{*}$ & $75.889^{\star}$ & $16446.750^{* *}$ & $88.313^{* *}$ & $0.190^{* *}$ & $5.347^{\mathrm{ns}}$ & $538880.472^{*}$ & $562150.231^{\mathrm{ns}}$ \\
\hline Error & 16 & 15.388 & 30.361 & 1385.278 & 8.636 & 0.036 & 8.009 & 325509.528 & 760406.944 \\
\hline Total & 35 & - & - & - & - & - & - & - & - \\
\hline
\end{tabular}

ns, * and ${ }^{* *}$ are non-significant and significant at 5 and $1 \%$ probability levels, respectively.

kg.ha ${ }^{-1}$, respectively (Table 4).

The effects of different crop rotations and crop residue levels on wheat yield and yield components are shown in Table 5.

The effects of different crop rotations on the plant height, spike number, seed number, economic and biological yield of wheat were significant $(p \leq 0.05)$. There was significant difference ( $p \leq 0.05)$ between different levels of crop residues to soil for wheat spike length, spike number and seed number. Interaction between different crop rotation and returning crop residues to soil had significant effect $(p \leq 0.05)$ on wheat height, spike length, seed number, economic yield and biological yield (Table 5).

\section{Growth traits and yield components of wheat}

The maximum wheat height was observed in wheat-wheat-wheat-rape seed-wheat with 89.2 $\mathrm{cm}$ and the minimum was for wheat-sugar beetwheat-potato-wheat with $77.7 \mathrm{~cm}$, respectively (Figure 1).

Mean comparisons of different crop rotations on wheat yield components are indicated in Table 6 . The highest spike number, seed number and
1000 -seed weight were for wheat-wheat-wheatrape seed-wheat ( 570.10 spikes per $\left.\mathrm{m}^{2}\right)$, wheat monoculture (44.96 seeds per spike) and wheatsugar beet-wheat-potato-wheat $(46.84 \mathrm{~g})$ respectively. The lowest spike number (403.20 spikes per $\mathrm{m}^{2}$ ) and 1000-seed weight $(45.44 \mathrm{~g})$ were observed in wheat monoculture and the lowest seed number was for wheat-wheat-wheatrape seed-wheat (40.67 seeds per spike) (Table $6)$.

The highest economic (7855 kg.ha $\left.{ }^{-1}\right)$ and biological (17990 kg.ha-1) yield of wheat were obtained for wheat-wheat-wheat-rapeseed-wheat and the lowest was for wheat monoculture with 5754 and $15920 \mathrm{~kg} \cdot \mathrm{ha}^{-1}$, respectively. Seed yield were increased 37, 21 and 33\% in WWWRW WSWPW, WMWPW compared with wheat monoculture (Figure 2)

Mean comparison of returning crop residues to soil on yield components for wheat are shown in Table 7.

The maximum spike number was observed in $100 \%$ returning crop residues to soil $(508.50$ spikes per $\mathrm{m}^{2}$ ) and the highest seed number and 1000 -seed weight were for $50 \%$ returning crop residues to soil (44.12 spikes per $\mathrm{m}^{2}$ and $46.69 \mathrm{~g}$, respectively). The minimum spike number, seed number and 1000-seed weight were obtained in 50,0 and $100 \%$ returning crop residues to soil with 464.80 spikes per $\mathrm{m}^{2}, 40.25$ spikes per $\mathrm{m}^{2}$ and $45.71 \mathrm{~g}$, respectively (Table 7).

The highest spike length was observed in $50 \%$ returning crop residues to soil with $88.0 \mathrm{~mm}$ and the lowest was for $100 \%$ returning crop residues to soil with $81.3 \mathrm{~mm}$ (Figure 3).

\section{Interaction between crop rotation and levels of returning crop residues to soil on growth characteristics and yield components of wheat}

The interaction between different crop rotations and levels of returning crop residues to soil on quantitative and qualitative characteristics of wheat are shown in Table 8.

The maximum economic yield was observed in wheat-wheat-wheat-rapeseed-wheat and 100\% returning crop residues to soil $\left(8488.00 \mathrm{~kg} \cdot \mathrm{ha}^{-1}\right)$ and the minimum was for wheat monoculture and $100 \%$ returning crop residues to soil $(5639.00$ $\left.\mathrm{kg} \cdot \mathrm{ha}^{-1}\right)$. The highest biological yield was obtained for wheat-wheat-wheat-rapeseed-wheat and $50 \%$ returning crop residues to soil and wheat-sugar beet-wheat-potato-wheat and 50\% returning crop 


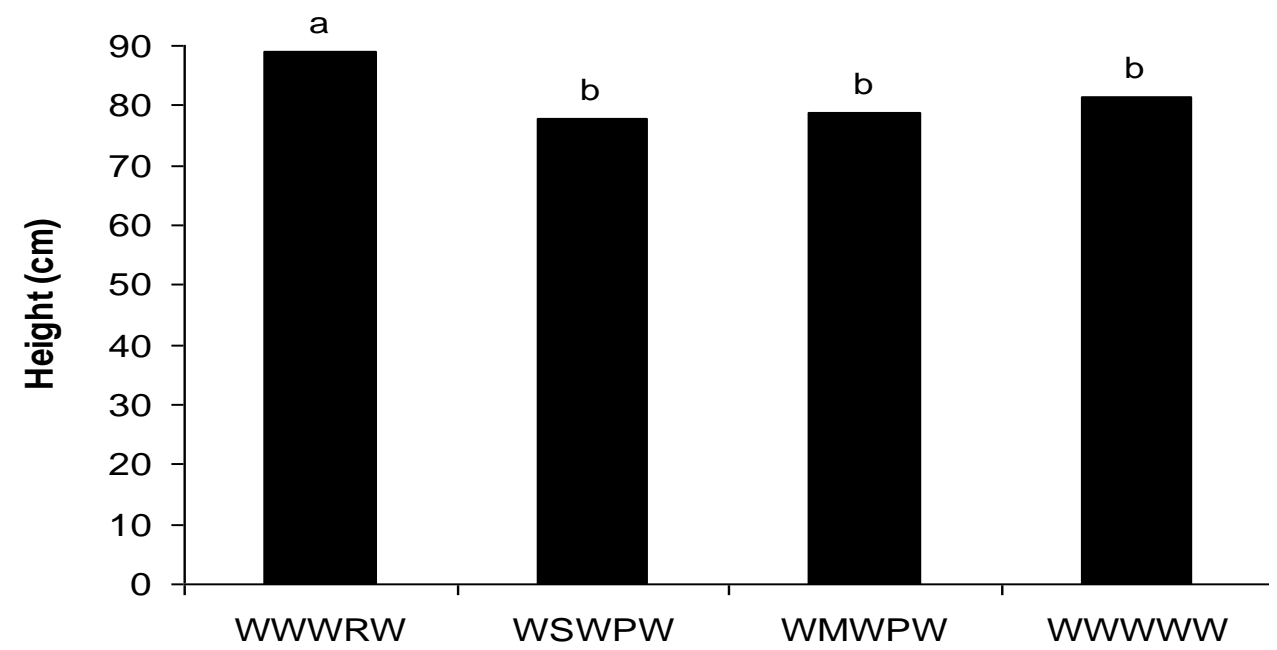

Figure 1. The effects of different crop rotations on wheat height $(\mathrm{cm})$ at the final year of study (2010). W, R, S, P and M are wheat, rape seed, sugar beet, maize and potato, respectively. Means with different letters are significantly different based on Duncan's multiple range test ( $\alpha=$ 0.05).

Table 6. The effects of different crop rotations on yield components of wheat at the final year of study (2010).

\begin{tabular}{lccc}
\hline Crop rotation & Spike number per $\mathbf{m}^{2}$ & Seed number per spike & 1000-seed weight $\mathbf{( g )}$ \\
\hline WWWRW & $570.10^{\mathrm{a}}$ & $40.67^{\mathrm{b}}$ & $46.83^{\mathrm{a}}$ \\
WSWPW & $469.20^{\mathrm{c}}$ & $41.62^{\mathrm{b}}$ & $46.84^{\mathrm{a}}$ \\
WMWPW & $503.66^{\mathrm{b}}$ & $41.40^{\mathrm{b}}$ & $45.79^{\mathrm{a}}$ \\
WWWWW & $403.20^{\mathrm{d}}$ & $44.96^{\mathrm{a}}$ & $45.44^{\mathrm{a}}$ \\
\hline
\end{tabular}

$\mathrm{W}, \mathrm{R}, \mathrm{S}, \mathrm{P}$ and $\mathrm{M}$ are wheat, rape seed, sugar beet, maize and potato, respectively. Means with different letters in each column are significantly different based on Duncan's multiple range test $(\alpha=0.05)$.

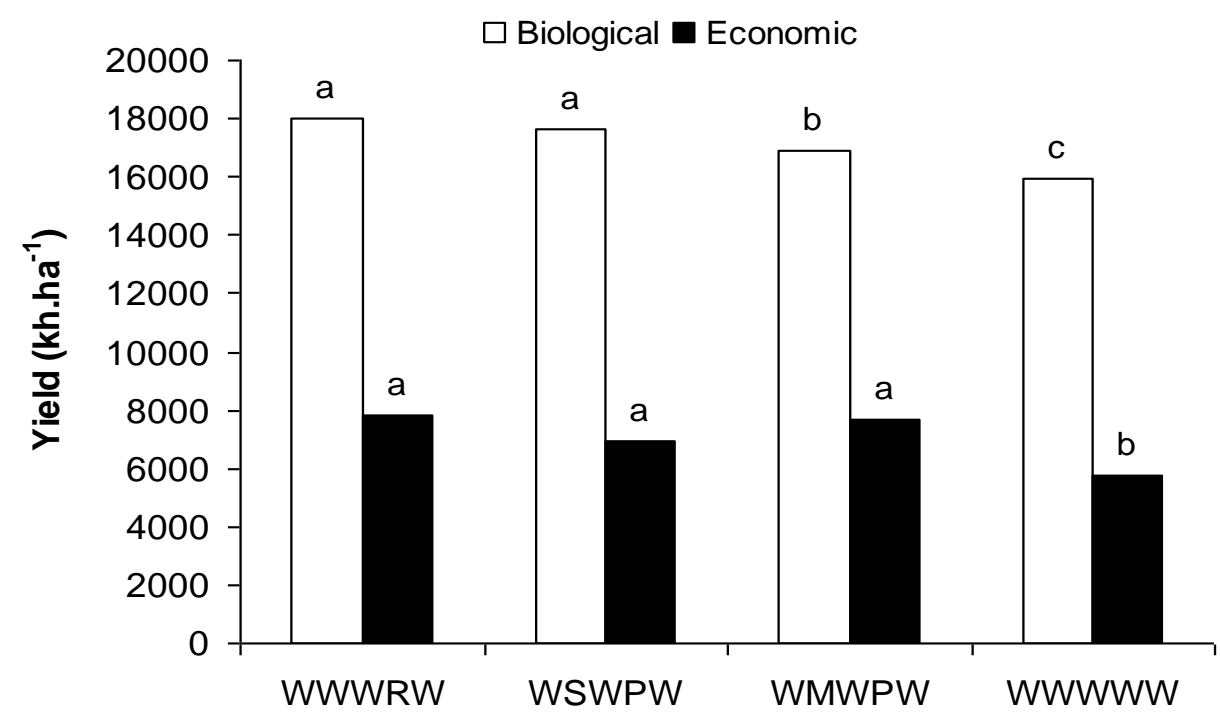

Figure 2. The effects of different crop rotations on economic and biological yield of wheat $\left(\mathrm{kg} . \mathrm{ha}^{-1}\right.$ ) at the final year of study (2010). W, R, S, P and M are wheat, rape seed, sugar beet, maize and potato, respectively. Means with different letters are significantly different based on Duncan's multiple range test $(\alpha=0.05)$. 
Table 7. The effects of different levels of returning crop residues to soil (\%) on yield components of wheat at the final year of study (2010).

\begin{tabular}{lcccc}
\hline Treatments & & Spike number per $\mathbf{m}^{2}$ & Seed number per spike & 1000-seed weight (g) \\
\hline \multirow{2}{*}{ Returning crop } & 0 & $486.30^{\mathrm{ab}}$ & $40.25^{\mathrm{b}}$ & $46.18^{\mathrm{a}}$ \\
residues to soil (\%) & 50 & $464.80^{\mathrm{b}}$ & $44.12^{\mathrm{a}}$ & $46.79^{\mathrm{a}}$ \\
& 100 & $508.50^{\mathrm{a}}$ & $42.12^{\mathrm{ab}}$ & $45.71^{\mathrm{a}}$ \\
\hline
\end{tabular}

Means with different letters in each column are significantly different based on Duncan's multiple range test $(\alpha=0.05)$.

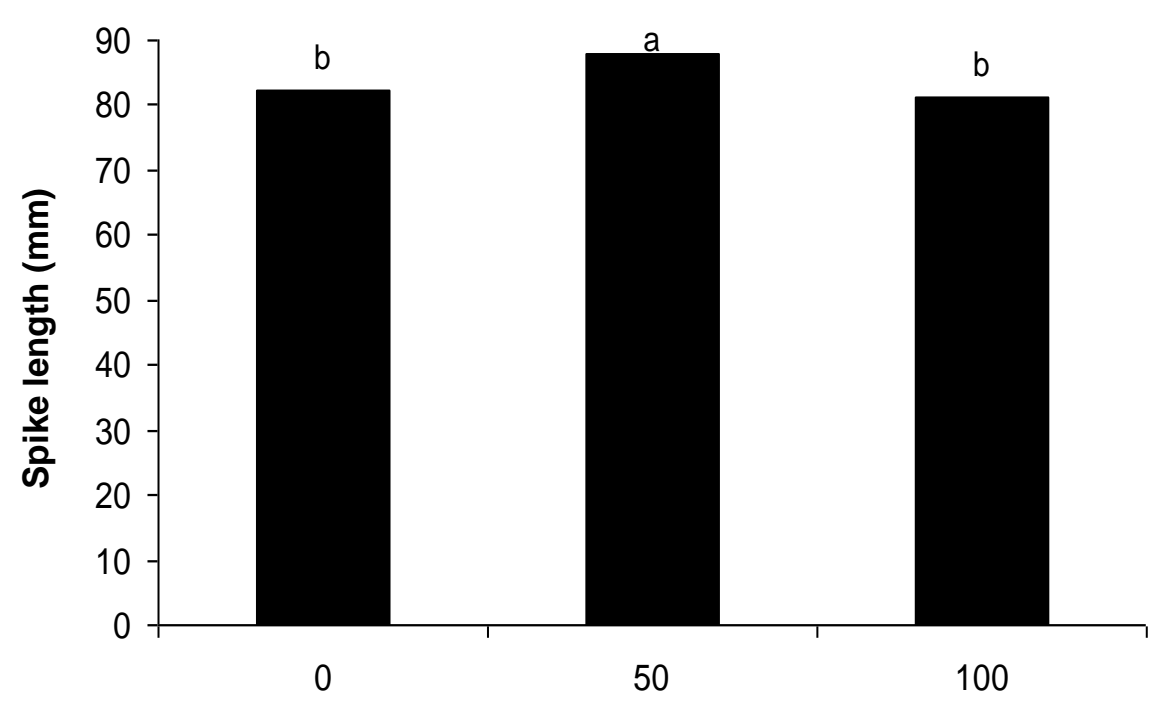

Returning crop residues to soil (\%)

Figure 3. Effect of different levels of returning crop residues to soil (0,50 and 100\%) on wheat spike length $(\mathrm{mm})$. Means with different letters are significantly different based on Duncan's multiple range test $(\alpha=0.05)$.

residues to soil with $18090.00 \mathrm{~kg} \cdot \mathrm{ha}^{-1}$ and the lowest was for wheat monoculture and $100 \%$ returning crop residues to soil with $15520.00 \mathrm{~kg} \cdot \mathrm{ha}^{-1}$. The maximum and the minimum plant height were observed in wheat-wheatwheat-rape seed-wheat and 50\% returning crop residues to soil with $91.29 \mathrm{~cm}$ and wheat-sugar beet-wheat-potatowheat and $100 \%$ returning crop residues to soil with $75.27 \mathrm{~cm}$, respectively. The highest spike length was obtained for wheat-wheat-wheat-rape seed-wheat and $50 \%$ returning crop residues to soil $(98.00 \mathrm{~mm})$ and the lowest was for wheat-sugar beet-wheat-potato-wheat and $0 \%$ returning crop residues to soil and wheat-sugar beetwheat-potato-wheat and $50 \%$ returning crop residues to soil $(82.00 \mathrm{~mm})$. The maximum and the minimum spike number were achieved in wheat-wheat-wheat-rape seedwheat and $0 \%$ returning crop residues to soil and wheatsugar beet-wheat-potato-wheat and $100 \%$ returning crop residues to soil with 621.00 and 437.70 spikes per $\mathrm{m}^{2}$, respectively. The highest seed number and spike weight were observed in wheat-wheat-wheat-wheat-rape seed- wheat and $0 \%$ returning crop residues to soil $(50.20$ seeds per spike and $2.29 \mathrm{~g}$, respectively) and the lowest were for wheat monoculture and $0 \%$ returning crop residues to soil (33.67 seeds per spike and $1.54 \mathrm{~g}$, respectively) (Table 8 ).

\section{DISCUSSION}

There are much potential to use crop rotation for maintaining the sustainability and productivity of agroecosystems (Delgado et al., 1998), especially for systems with low soil organic matter. Crop rotation is a key component for maintaining the sustainability of agricultural systems (Limon-Ortega et al., 2008). Different crops in sequence with wheat changes the growth characteristics, yield components and seed yield. Generally, determining which crops to include in a rotation depends on farmer's management facilities, soil productivity and fertility, available planting and harvesting equipments and weed and pest competition. In the Rokh 


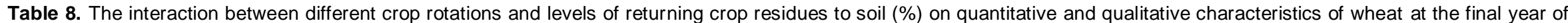
study (2010).

\begin{tabular}{|c|c|c|c|c|c|c|c|c|}
\hline $\begin{array}{l}\text { Crop } \\
\text { rotation }\end{array}$ & $\begin{array}{c}\text { Returning crop } \\
\text { residues to soil (\%) }\end{array}$ & $\begin{array}{c}\text { Economic yield } \\
\left(\mathrm{kg} \cdot \mathrm{ha}^{-1}\right)\end{array}$ & $\begin{array}{c}\text { Biological yield } \\
\left(\mathrm{kg}^{\left.-\mathrm{ha}^{-1}\right)}\right.\end{array}$ & $\begin{array}{c}\text { Height } \\
\text { (cm) }\end{array}$ & $\begin{array}{c}\text { Spike length } \\
(\mathrm{mm})\end{array}$ & $\begin{array}{c}\text { Spike number } \\
\text { per } \mathrm{m}^{2}\end{array}$ & $\begin{array}{c}\text { Seed number } \\
\text { per spike }\end{array}$ & $\begin{array}{c}\text { Spike weight } \\
(\mathrm{g})\end{array}$ \\
\hline \multirow{3}{*}{ WWWRW } & 0 & $7006.00^{\mathrm{bc} *}$ & $17790.00^{\mathrm{ab}}$ & $87.47^{\mathrm{abc}}$ & $82.67^{\mathrm{b}}$ & $621.00^{\mathrm{a}}$ & $33.67^{\mathrm{e}}$ & $1.54^{\mathrm{d}}$ \\
\hline & 50 & $8071.00^{\mathrm{ab}}$ & $18090.00^{\mathrm{a}}$ & $91.29^{a}$ & $98.00^{\mathrm{a}}$ & $547.00^{b}$ & $42.20^{\mathrm{bcd}}$ & $2.00^{\mathrm{abd}}$ \\
\hline & 100 & $8488.00^{\mathrm{a}}$ & $18080.00^{\mathrm{a}}$ & $88.80^{\mathrm{ab}}$ & $80.00^{b}$ & $542.30^{\mathrm{b}}$ & $46.13^{\mathrm{ab}}$ & $2.07^{\mathrm{ab}}$ \\
\hline \multirow{3}{*}{ WSWPW } & 0 & $7033.00^{\mathrm{bc}}$ & $17980.00^{\mathrm{a}}$ & $78.73^{d}$ & $80.00^{b}$ & $512.30^{\mathrm{bc}}$ & $42.60^{\mathrm{bcd}}$ & $1.90^{\mathrm{bc}}$ \\
\hline & 50 & $6514.00^{\text {cd }}$ & $18090.00^{\mathrm{a}}$ & $79.13^{d}$ & $88.00^{\mathrm{b}}$ & $457.70^{c d}$ & $39.87^{\mathrm{cd}}$ & $2.04^{\mathrm{ab}}$ \\
\hline & 100 & $7279.00^{\mathrm{bc}}$ & $16770.00^{\mathrm{abc}}$ & $75.27^{d}$ & $82.00^{\mathrm{b}}$ & $437.70^{d}$ & $42.40^{\mathrm{bcd}}$ & $1.82^{\mathrm{bcd}}$ \\
\hline \multirow{3}{*}{ WMWPW } & 0 & $7524.00^{\mathrm{abc}}$ & $16810.00^{\mathrm{abc}}$ & $76.07^{d}$ & $82.00^{b}$ & $489.70^{\mathrm{bcd}}$ & $37.27^{\text {de }}$ & $1.83^{\mathrm{bcd}}$ \\
\hline & 50 & $7538.00^{\mathrm{abc}}$ & $16780.00^{\mathrm{abc}}$ & $80.60^{c d}$ & $82.00^{\mathrm{b}}$ & $511.00^{\mathrm{bc}}$ & $42.73^{\mathrm{bcd}}$ & $1.75^{\mathrm{bcd}}$ \\
\hline & 100 & $7970.00^{\mathrm{ab}}$ & $17150.00^{\mathrm{abc}}$ & $79.40^{d}$ & $78.00^{\mathrm{b}}$ & $510.00^{\mathrm{bc}}$ & $44.20^{\mathrm{bc}}$ & $1.83^{\mathrm{bcd}}$ \\
\hline \multirow{3}{*}{ WWWWW } & 0 & $5751.00^{d}$ & $15980.00^{c}$ & $82.73^{\mathrm{bcd}}$ & $84.67^{b}$ & $322.30^{\mathrm{e}}$ & $50.20^{a}$ & $2.29^{\mathrm{a}}$ \\
\hline & 50 & $5873.00^{d}$ & $16250.00^{\mathrm{bc}}$ & $81.40^{\mathrm{cd}}$ & $88.00^{b}$ & $344.30^{\mathrm{e}}$ & $47.47^{\mathrm{ab}}$ & $2.02^{\mathrm{ab}}$ \\
\hline & 100 & $5639.00^{d}$ & $15520.00^{c}$ & $80.27^{\mathrm{cd}}$ & $83.33^{b}$ & $543.00^{\mathrm{b}}$ & $37.20^{\text {de }}$ & $1.63^{\mathrm{cd}}$ \\
\hline
\end{tabular}

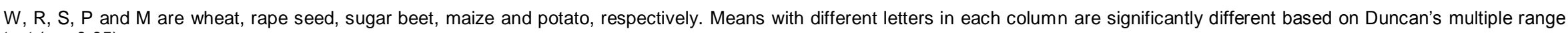
test $(\alpha=0.05)$.

plain, wheat is typically rotated with maize, rapeseed, potato and sugar beet, although sometimes other factors such as weather conditions, soil fertility, water deficit and labor availability restricted farmers to sown wheat after wheat. Sowing wheat in rotation with other crops improves seed yield compared with monoculture.

Rape seed has compounds that are enzymatically hydrolyzed upon tissue disruption to release a variety of biologically active compounds, including isothiocyanates, which are toxic to certain insects (Blau et al., 1978), fung (Muehlchen et al., 1990), nematodes (Mojtahedi et al., 1993) and weeds (Bell and Muller, 1973). Also, Altieri and Doll (1978) reported that it is a potent allelopathic crop and has allelopathic effects on weeds. Rice (1984) reported that rape seed is a good allelopathic crop for weed control. So, it seems that the production of allelochemicals to soil after rape seed planting decreases the weed growth and pest population (Rice, 1984 Oleszek et al., 1996) and improves wheat yield.

The present study showed that the growth characteristics and yield of wheat were significantly enhanced in crop rotation compared with wheat monoculture (Table 6, Figures 1 and 2). This might be due to increasing weeds, pests and diseases in wheat monoculture compared with other crop rotations. Therefore, continuous wheat often increased herbichemical requirement and decreased soil organic carbon and physical and chemical soil characteristics compared with other crop rotations (Edwards et al., 2000; Popovici and Bucurean, 2009).
The yield loss in wheat monoculture could be attributed chiefly to reduction in the spike number per $\mathrm{m}^{2}$. The decline in the 1000-seed weight was smaller in magnitude. In a monoculture, the reduction in spike number was as great as $14 \%$ and therefore, in the present study the highest spike number (570.10 spikes per $\mathrm{m}^{2}$ ) was observed in WWWRW (Table 6). Other results such as Berzsenyi et al. (2000) also confirmed positive effects of rotation of maize on wheat yield. Different crop rotation of wheat with other crops especially rapeseed improved yield and yield components compared with monoculture. Seibutis et al. (2009) confirmed the role of preceding spring rapeseed in increasing of wheat yield and its components and seed demonstrate the beneficial effects of crop rotation in wheat 
demonstrate the beneficial effects of crop rotation in wheat production. Crop rotation significantly affected wheat growth characteristics and its yield. Rotation of wheat with rapeseed increased yield and yield components. Wheat seed yield was increased up to $37 \%$ in wheat-wheat-wheat-rape seed-wheat compared with wheat monoculture. In addition, spike number was also significantly greater when grown in rotation was compared with wheat monoculture (Table 6, Figure 2).

Increase in organic carbon due to crop residue retention was closely associated with greater input of carbon to soil through crop residue. The decline of soil $\mathrm{C}$ with removal of crop residue suggests that the practice of removing crop residue from fields for on-farm and industrial uses in the long run may result in soil degradation (Campbell et al., 1998). Results from numerous studies have shown that various amounts of crop residues affect soil properties and crop yields (Larson et al., 1972; Black, 1973). Retaining crop residue often improves the capacity of soil to store water and could be improve crop yield (Malhi and ÓSullivan, 1990; Singh et al., 1998). Other researches in the Canadian prairies have also confirmed similar effects of crop residue management on soil structure (Singh et al., 1994; Singh and Malhi, 2006). Usually, those studies showed that returning increased amounts of crop residues increased soil organic matter content, microbial activity, nutrient availability, water infiltration and storage and crop yields (Fribourg and Bartholomew, 1965; Unger and McCalla, 1980; Prasad and Power, 1991). Power et al. (1998) examined the effects of different levels of crop residues $(0,50,100$ and $150 \%$ of the quantity produced by the previous crop) on maize yield. They reported that residual effects of the $150 \%$ residues amount increased corn grain production $16 \%$ compared with $0 \%$ (4900 vs. $4250 \mathrm{~kg} \cdot \mathrm{ha}^{-1}$, respectively). The application of crop residues affected wheat yield and yield components. So, the highest was observed in $100 \%$ returning crop residues to soil. Although the practice of adding crop residues to soil is feasible alternative for farmers to enhance yield, the quantity and quality residue is the main factor for incorporation, hence the crop residue level is determinant element.

\section{REFERENCES}

Akobundu IO, Ekeleme F (2002). Weed seedbank characteristics of arable fields under different fallow management systems in the humid tropical zone of southern Nigeria. Agrofor. Syst. 54:161-170.

Altieri MA, Doll JD (1978). The potential of allelopathy as a tool for weed management in crops. PANS, USA 24:495-502.

Bélair G, Parent LE (1996). Using crop rotation to control Meloidogyne hapla Chitwood and improve marketable carrot yield. HortScience 31(1):106-108.

Bell DT, Muller CH (1973). Dominance of California annual grasslands by Brassica nigra. Am. Midl. Nat. 90:277-299.

Berzsenyi Z, Győrffy B, Lap DQ (2000). Effect of crop rotation and fertilisation on maize and wheat yields and yield stability in a longterm experiment. Eur. J. Agron. 13(2-3):225-244.

Black AL (1973). Soil Property changes with crop residue management in a wheat-fallow rotation. Soil Sci. Soc. Am. J. 37:943-946.
Blau PA, Feeny P, Contardo L, Robson DS (1978). Allylglucosinolate and herbivorous caterpillars (a contrast in toxicity and tolerance). Science 200:1296-1298.

Blevins RL, Frye WW (1993). Conservation tillage: an ecological approach to soil management Adv. Agron. 51:33-76.

Campbell CA, Selles F, Lafond GP, McConkey BG, Hahn D (1998). Effect of crop management on $\mathrm{C}$ and $\mathrm{N}$ in long-term crop rotations after adopting no-tillage management (comparison of soil sampling strategies). Can. J. Soil Sci. 78:155-162.

Chalk PM (1998). Dynamics of biologically fixed $\mathrm{N}$ in cereal-legume rotations: a review. Aust. J. Agric. Res. 49:303-316.

Chikoye D, Akobundu IO, Ekeleme F (2000). Long-term effects of Pueraria phaseoloides (Roxb.) Benth and Leuceana leucocephala (Lam.) with fallow on weed growth and composition in cassava intercropped with maize. In 'Proceedings, of the International Seminar, Dakar. John Libbey Eurotext, Paris, France, pp. 603-610.

Delgado JA, Follett RF, Sharkoff JL, Brodahl MK, Shaffer MJ (1998). NLEAP facts about nitrogen management. J. Soil Water Conserv. 53:332-338.

Edwards L, Burney JR, Richer G, MacRae AH (2000). Evaluation of compost and straw mulching on soil-loss characteristics in erosion plots of potatoes in Prince Edward Island, Canada. Agric. Ecosyst. Environ. 81:217-222.

Farahani HJ, Peterson GA, Westfall DG (1998). Dryland cropping intensification: a fundamental solution to efficient use of precipitation. Adv. Agron. 64:197-223.

Fribourg HA, Bartholomew UV (1965). Availability of nitrogen from crop residues during the first and second year after application. Proc. Soil Sci. Soc. Am. 20:505-508.

Kanmegne J, Degrande A (2002). From alley cropping to rotational fallow: farmers' involvement in the development of fallow management techniques in the humid forest zone of Cameroon. Agrofor. Syst. 54:115-120.

Karlen DL, Varvel GE, Bullock DG, Cruse RM (1994). Crop rotations for the $21^{\text {st }}$ century. Adv. Agron. 53:1-45.

Lal R (1989). Conservation tillage for sustainable agriculture: tropics versus temperate environments. Adv. Agron. 42:85-197.

Larson WE, Clap CE, Pierre WH, Morachan YB (1972). Effects of increasing amounts of organic residues on continuous corn: II. Organic carbon, nitrogen, phosphorus and sulphur. Agron. J. 64:204208.

Liebman M, Dyck E (1993). Crop rotation and intercropping strategies for weed management. J. Appl. Ecol. 3:92-122.

Limon-Ortega A, Govaerts B, Sayre KD (2008). Straw management, crop rotation and nitrogen source effect on wheat grain yield and nitrogen use efficiency. Eur. J. Agron. 29:21-28.

Liu DL, Lovett JV (1990). Allelopathy in barley: Potential for biological suppression of weeds. In 'Proceedings, alternatives to the Chemical Control of Weeds, (Rotorua, New Zealand, Ministry of Forestry, FRI Bull. 155:85-92).

López-Bellido L, Fuentes M, Castillo JE, López-Garrido FJ (1998). Effects of tillage, crop rotation and nitrogen fertilization on wheatgrain quality grown under rainfed Mediterranean conditions. Field Crop Res. 57(3):265-276.

Malhi SS, Ósullivan PA (1990). Soil temperature, moisture and compaction under zero and conventional tillage in central Alberta. Soil Till. Res. 17:173-179.

Maskina MS, Power JF, Doran JW, Wilhelm WW (1993). Residual effects of no-till crop residues on corn yield and nitrogen uptake. Soil Sci. Soc. Am. J. 57:1555-1560.

Mojtahedi H, Santo G, Wilson J, Hang AN (1993). Managing Meloidogyne chitwoodi on potato with rapeseed as green manure. Plant Dis. 77:42-46.

Muehlchen A, Rand R, Parke J (1990). Evaluation of crucifer green manures for controlling aphanomyces root rot of peas. Plant Dis. 74: 651-654.

Oleszek W, Ascard J, Johansson H (1996). Brassicacae as alternative plants for weed control in sustainable agriculture Scientific Publishers, Jodhpur, India, pp. 3-22

Parente G (1996). Grassland and land use systems. In 'Proceedings, Sixteenth Meeting. Grassland and Land Use Systems. (EGF. ERSA, Gorizia, Italy). 
Peterson GA, Westfall DG, Cole C (1993). Agroecosystem approach to soil and crop management. Soil Sci. Soc. Am. J. 57:1354-1360.

Phillips RE, Blevins RL, Thomas GW, Frye WW, Phillips SH (1980). No-tillage agriculture. Science 208:1108-1113.

Popovici M, Bucurean E (2009). The influence of crop rotation over the yield and the quality of the seeds for the dropia autumn wheat cultivar. Res. J. Agric. Sci. 41(1):99-102.

Power JF, Koerner PT, Doran JW, Wilhelm WW (1998). Residual effects of crop residues on grain production and selected soil properties. Soil Sci. Soc. Am. J. 62:1393-1397.

Prasad R, Power JF (1991). Crop residue management- literature review. Adv. Soil Sci. 15:205-251.

Rice EL (1984). Allelopathy. $2^{\text {nd }}$ Ed. Academic Press, Inc. Orlando, Florida.

Scherr SJ, Yadav Y (1996). Land degradation in the developing world: Implications for food, agriculture and the environment to 2020. Food, Agriculture and the Environment Discussion paper 14 (International Food Policy Research Institute, Washington, DC).

Schrieber MM (1992). Influence of tillage, crop rotation and weed management on giant foxtail (Setaria faberi) populations dynamics and corn yield. Weed Sci. 40:645-653.

Seibutis W, Deveikytė I, Feiza V (2009). Effects of short crop rotation and soil tillage on winter wheat development in central Lithuania. Agron. Res. 7:471-476.
Singh B, Malhi SS (2006). Response of soil physical properties to tillage and residue management on two soils in a cool temperate environment. Soil Till. Res. 85:143-153.

Singh B, Chanasyk DS, McGill WB (1998). Soil water regime under barley with long-term tillage-residue systems. Soil Till. Res. 45:5974.

Singh B, Chanasyk DS, McGill WB, Nyborg MPK (1994). Residue and tillage management effects on soil properties of a typic cryoboroll under continuous barley. Soil Till. Res. 32:117-133.

Toderi G (1988). II ruolo del prato sulla fertilità del terreno [Role of the meadow in the soil fertility]. In ' Futuro della Foraggicoltura Prativa nella Pianura Padana' (ISCF, Lodi, Italy).

Unger PW, McCalla TM (1980).Conservation tillage systems. Adv. Agron. 33:1-58.

Zentner RP, Lindwall CW (1978). An economic assessment of zero tillage in wheat-fallow rotations in southern Alberta. Can. Farm Econ. 136:1-6. 